extraordinary fruit hybrids became fertile, while under the master's hand a hazel sprouted from a hornbeam.

During Stalin's lifetime the succession of claims was too rapid to disprove and too dangerous to contradict. But when he died critics raised their heads. And when Khrushchev, three years later, announced a thaw, they dared to open their mouths. The fact that none of Lysenko's claims had ever been vindicated might now, it seemed, prove to be his undoing. But matters of state are not to be so easily disentangled. As can happen even in a free world the industries of communication and education were now implicated with the establishment in a general deception. They were also infiltrated by the secret police. What was worse, it turned out that the successor, Khrushchev himself, liked Lysenko; not as Stalin did, for his theory but for his earthy language and proverbial wisdom.

So it was that Lysenko enjoyed one last spell of power. The virgin lands of Kazakhstan and the novel possibilities of cattle breeding offered him new fields to conquer. The two men embarked on these ventures in partnership and their failure seems to have contributed to the downfall of both. For Zhores Medvedev's exposure of this failure in Samizdat led to his confinement in a psychiatric clinic. But it had been known to the Praesidium before it deposed Khrushchev on October 14, 1964. The customary newspaper campaign followed. But now, for the first time, it was turned against Lysenko. He was dismissed as head of the Academy's Institute of Genetics on February 1, 1965. And the Institute itself (not for the first time) was dissolved.

News of these developments was released abroad. But the Russian public were only by rumour allowed to perceive that a great pillar of the state had somehow been withdrawn; and to feel that two systems of belicf, abandoning the struggle to the death, were to be allowed to shake down together. When summer arrived, sure enough. the Academy in Moscow was allowed to celebrate the centenary of Mendel's paper and to dispatch to Brno in Czechoslovakia seventy geneticists, the largest of all delegations, to lay a wreath on the Abbot's monument.

Thus everything, it seemed, could now be amicably and democratically arranged. Lysenko, for his part, could remain a member of three academies. He could keep his titles and pension, his following of university professors. his journal regularly published and his Experiment Farm in the Lenin Hills. And the grateful geneticists were free to pick up what they could, first in medical, then in animal, and ultimately in plant genetics, from the ruins that Lysenko had left them. Meanwhile the Government could forget that it had ever interfered in these academic matters.

Outside Russia, however, the damage that had been done to the relations between scientists and communism could never be repaired. The view of communism as meaning the liberation of science, held in the 1920 s had been turned inside out. With this painful reservation, inside $\mathrm{Russia}$, it is a hopeful sign that the restored geneticists are proposing to hold in Moscow in August 1977 the International Congress on Genetics so tragically abandoned forty years ago. The history, the theory, and the philosophy of genetics are not among the 35 headings proposed for discussion. But, no doubt, the names of the men whom Lysenko destroyed will be discreetly remembered.

One more question should be asked: was Lysenko a charlatan? It is an important question because fraud is always, and in all countries, bound to collect in the wide fringes of science. He was obviously ill-educated, quite shallow, very cunning and a little deranged. As Vavilov put it, privately, he was "an angry man" of a kind we all know. And he found his anger brought him great rewards. On the other hand, his followers were far from angry. They had calculated the rewards that a corrupt system had to offer them.

It remains to say that the world of science owes a debt to three bodies of men in connection with Lysenko. There were those like Vavilov who died in fulfilling their duty. There are those like Andrei Sakharov and Zhores Medvedev who resisted and survived. And there are those devoted scholars outside Russia, notably David Joravsky and Loren Graham, who have enabled us now to understand so much of what happened.

C. D. Darlington

\section{S. B. Pessôa}

The Death of Professor Samuel Barnsley Pessôa, removed the grand master of parasitology from Latin America, a region where the subject has flourished vigorously throughout this century. His predecessors in Brazil included $H$. de Beaupaire Aragão, Carlos Chagas, $H$. da Rocha Lima and Oswaldo Cruz. Pessôa himself founded a school of workers who have penetrated into all corners of South and Middle America. The training of the first generation stemmed from their close association with German, French and Italian scientists either directly in the New World or during their own visits to Europe in pre-world war days. Pessôa's monumental book, Parasitologia Médica, has gone through many editions and is in constant use in
Portuguese and Spanish speaking countries.

Pessôa was born in São Paulo on June 4, 1898, the son of Leonel Pessôa and Anna Barnsley, who was of English descent. He spent the greater part of his life in São Paulo, and died there on September 3, 1976.

After qualifying in medicine, he entered in 1925 the General Prophylactic Service of the State of São Paulo as an experimental officer attached to the Institute of Hygiene. His work took him far afield and he quickly became acquainted with the severe sanitary problems of the rural areas as well as those of the city. The distress and poverty of so much of the population transformed him into an ardent fighter for the abolition of the system, which accepted this situation with equanimity, and his ideas became increasingly revolutionary.

His abilities were quickly recognised both in the academic and in administrative fields: he was appointed to a Chair in the Faculty of Medicine of the University of São Paulo in 1931 and was later made Director General of Health. In the latter role he entirely re-organised the service by starting large scale campaigns against endemic diseases and initiating research projects. He took an active part in the latter and made many original contributions notably in muco-cutaneous leishmaniasis, trachoma and schistosomiasis. His observations on espundia and on the transmission of this form of leishmaniasis were fundamental. He studied the epidemiology of Chagas' disease and disentangled some of the problems of the cardiac complications and other phenomena of 'mega'.

Pessôa's reputation was so great that he was appointed to numerous chairs throughout Brazil and even in his last years, he was still commuting between different universities from one end (e.g. Goiás) of Brazil to the other (e.g. Santa Catarina). Pessôa never hesitated to express his views and he was often threatened with prison or dismissal. In the last 1.5 or 20 years of his life, he became entranced by the parasitic protozoa of snakes and lizards, working both at the Institute of Butantan and in the field on these parasites, which had always attracted Brazilian scientists; he disclosed many new species and methods of transmission by leeches and other invertebrates.

Pessôa was a colourful character, always welcome in international gatherings, where his astute and original mind was much appreciated. But above all, he was revered by his past pupils who could count both on his loyalty and protection during trials and persecutions, and invaluable advice regarding their scientific problems.

P. C. C. Garnham 